\title{
Alpha Amylase from a Fungal Culture Grown on Oil Cakes and Its Properties
}

\author{
Sumitra Ramachandran ${ }^{1}$, Anil K. Patel ${ }^{1}$, Kesavan Madhavan Nampoothiri ${ }^{1}$, Sandhya \\ Chandran $^{1}$, George Szakacs ${ }^{2}$, Carlos Ricardo Soccol $^{3}$ and Ashok Pandey ${ }^{1 *}$ \\ ${ }^{1}$ Biotechnology Division; Regional Research Laboratory; CSIR; Trivandrum-695 019; India. ${ }^{2}$ Department of \\ Agricultural Chemical Technology; Technical University of Budapest; Hungary. ${ }^{3}$ Process Biotechnology \\ Laboratory; Department of Chemical Engineering; Federal University of Parana; Curitiba - PR - Brazil
}

\begin{abstract}
Solid-state fermentation was carried out for the production of $\alpha$-amylase using Aspergillus oryzae. Different oil cakes such as coconut oil cake (COC) sesame oil cake (SOC), groundnut oil cake (GOC), palm kernel cake (PKC) and olive oil cake (OOC) were screened to be used as substrate for the enzyme production and also compared with wheat bran (WB). GOC was found to be the best producer of the enzyme among these. Combination of WB and GOC (1:1) resulted higher enzyme titres than the individual substrates. Maximum amount of enzyme (9196 U/gds) was obtained when SSF was carried out using WB + GOC, having initial moisture of 64\% and supplemented with lactose and ammonium nitrate (1\% each) at $30^{\circ} \mathrm{C}$ for $72 \mathrm{~h}$ using $2 \mathrm{~mL}$ spore suspension (6x $10^{7}$ spores $\left./ \mathrm{ml}\right)$. Partial purification of the enzyme using ammonium sulphate fractionation resulted in 2.4-fold increase in the activity. The enzyme showed molecular weight of $68 \mathrm{KDa}$ by SDS-PAGE. Except Mn, all other metal ions such as Ca, K, $\mathrm{Na}, \mathrm{Mg}$ were found to be inhibitory for the enzyme activity. The enzyme was optimally active at $50^{\circ} \mathrm{C}$ and $\mathrm{pH}$ 5.0.
\end{abstract}

Key words: Alpha amylase, oil cakes, solid-state fermentation, partial purification, Aspergillus oryzae

\section{INTRODUCTION}

Alpha amylases are one of the important and widely used enzymes whose spectrum of applications has widened in many sectors such as clinical, medicinal and analytical chemistry. Besides their use in starch saccaharification they also find applications in food, baking, brewing, detergent, textile, paper, and distilling industry. Alpha amylases (endo-1, 4- $\alpha$-D-glucan glucohydrolase EC 3.2.1.1) constitute the family of endo amylases that randomly cleave the 1, 4- $\alpha$ D-glycosidic linkages between adjacent glucose units in the linear amylose chain with retention of $\alpha$-anomeric configuration in the products.
Production of fungal alpha amylases has been investigated through submerged $(\mathrm{SmF})$ and solidstate fermentation (SSF) (Carlsen et al., 1996, Francis et al. 2002, Pandey et al., 1999). However, it has been reported that SSF is the most appropriate process in developing countries due to the advantages it offers (Carrizales and Jaffe, 1986).The hyphal mode of fungal growth and their good tolerance to low water activity $\left(\mathrm{a}_{\mathrm{w}}\right)$ and high osmotic pressure conditions make fungi efficient and competitive in natural microflora for bioconversion of solid substrates (Raimbault, 1998). Oil cakes are byproducts obtained after oil extraction. Depending upon the extraction methods the chemical composition of oil cake

\footnotetext{
${ }^{*}$ Author for correspondence
} 
varies. These oilcakes are fairly rich in protein and are traditionally used as feed ingredients for farm animals. They are also used as aquaculture feeds (Singh et al., 2003). With the advent of biotechnological innovations, mainly in the area of enzyme and fermentation technology, many new areas have opened for their utilization as raw materials for the production of value added fine products (Pandey et al., 2000a, 2000b, 2001).

Oil cakes have been used as substrates in SSF for the production of glucoamylase by Aspergillus niger (Selvakumar et al., 1998), phytase by Rhizopus oligosporus (Sabu et al., 2002). lipase by Candida rugosa (Benjamin and Pandey 1996, 1997, 1998).Oil cakes are rich in fibre and have high concentration of non-starch polysaccharides (NSP). Their chemical composition varies due to the differences in the extraction methods of oil. Oil cakes such as palm kernel cake, sesame oil cake and coconut oil cake contain $14-20 \%$ of crude protein. However, groundnut oil cake contains $40-$ $50 \%$ of crude protein. Fat content of the oil cakes is also dependent on the oil extraction method. They generally have less than $2-3 \%$ fat (Swick, 1999).

The aim of this study was to evaluate the potential of oil cakes for the production of alpha amylase and also to study the properties of the enzyme produced in SSF after partial purification.

\section{MATERIALS AND METHODS}

\section{Microorganism, maintenance of culture}

A fungal strain of Aspergillus oryzae (IFO-30103) was used in this study. It was maintained on Potato-Dextrose-Agar (PDA) (Hi-media, Mumbai) medium. The slants were grown at $30^{\circ} \mathrm{C}$ for seven days and stored at $4^{\circ} \mathrm{C}$. These were sub-cultured fortnightly.

\section{Viable Spore Count}

The total viable spore number on a PDA slant was determined by colony count technique. The spores were suspended in $10 \mathrm{ml}$ of distilled water with $0.1 \%$ Tween 80 , using a sterile transfer needle and diluted serially. One $\mathrm{ml}$ of spore suspension was poured onto sterile Petri-plates, containing sterile PDA medium and spread uniformly. The inoculated Petri-plates were incubated at $30^{\circ} \mathrm{C}$ for 48h. A plate that developed between 7 to 200 colonies was selected for counting. The spore density was calculated as the count multiplied by the dilution factor.

\section{Preparation of inoculum}

Ten $\mathrm{ml}$ of distilled water containing $0.1 \%$ Tween80 was transferred to a sporulated ( 7 days old) PDA slant culture. The spores were dislodged using the inoculation needle under aseptic conditions and the suspension, with appropriate dilution was used as inoculum.

\section{Substrates}

Different oil cakes such as coconut oil cake (COC), sesame oil cake (SOC), groundnut oil cake (GOC), palm kernel cake (PKC) and olive oil cake (OOC) were used as substrate. PKC was a gift from Malaysian Palm Oil Research Institute, Kuala Lumpur; all other cakes were procured from the local market in Trivandrum. Wheat bran was also used as substrate to compare the enzyme yields produced by oil cakes.

\section{Solid-state fermentation}

Five grams of dry oil cake was taken into a $250 \mathrm{ml}$ Erlenmeyer flask and to this a salt solution $(5 \mathrm{ml})$ containing $(\mathrm{g} / \mathrm{l}) \mathrm{KH}_{2} \mathrm{PO}_{4} 2, \mathrm{NH}_{4} \mathrm{NO}_{3} 5, \mathrm{NaCl} 1$, $\mathrm{MgSO}_{4 .} .7 \mathrm{H}_{2} \mathrm{O} 1$ and distilled water was added to adjust the required moisture level. The contents of the flasks were mixed thoroughly and autoclaved at $121^{\circ} \mathrm{C}$ for $20 \mathrm{~min}$.

Unless otherwise mentioned, SSF was carried at $30^{\circ} \mathrm{C}$ with substrate initial moisture content of $64 \%$ for $72 \mathrm{~h}$ using $2 \mathrm{ml}$ spore suspension $\left(6 \times 10^{7}\right.$ spores $\left./ \mathrm{ml}\right)$ as inoculum. Studies were also performed to evaluate the influence of supplementation of substrate with different carbon sources such as glucose, maltose, starch, sucrose and lactose $(1 \%, \mathrm{w} / \mathrm{v})$ and nitrogen sources such as peptone, urea, corn-steep solid, sodium nitrate, ammonium sulphate and ammonium nitrate $(1 \%, \mathrm{w} / \mathrm{v})$.

WB was also used in combination with GOC to compare the enzyme production by mixed substrate fermentation.

\section{Dry weight determination}

Dry weight of the samples was determined by drying them in a hot air oven at $80^{\circ} \mathrm{C}$ for $24 \mathrm{~h}$.

\section{Enzyme extraction}

From the fermented matter, crude enzyme was extracted by mixing a known quantity of fermented matter with distilled water containing 
$0.1 \%$ Tween-80 on a rotary shaker $(180 \mathrm{rpm})$ for one $\mathrm{h}$. The suspension was then centrifuged at $7000 \mathrm{x} \mathrm{g}$ at $4^{\circ} \mathrm{C}$ for $10 \mathrm{~min}$ and the supernatant was used for enzyme assay.

\section{$\alpha$-amylase assay}

$\alpha$-amylase activity was determined as described by Okolo et al. (1995). The reaction mixture consisted of $1.25 \mathrm{ml}$ of $1 \%$ soluble starch, $0.25 \mathrm{ml} 0.1 \mathrm{M}$ acetate buffer ( $\mathrm{pH} 5.0$ ), $0.25 \mathrm{ml}$ of distilled water, and $0.25 \mathrm{ml}$ of crude enzyme extract. After 10 min of incubation at $50^{\circ} \mathrm{C}$, the liberated reducing sugars (glucose equivalents) were estimated by the dinitrosalicylic acid (DNS) method of Miller (1959). The colour developed was read at 575nm using a Shimazdu UV-160A spectrophotometer. Glucose was used as the standard. The blank contained $0.5 \mathrm{ml}$ of $0.1 \mathrm{M}$ acetate buffer $(\mathrm{pH} 5.0)$, $1.25 \mathrm{ml} 1 \%$ starch solution and $0.25 \mathrm{ml}$ distilled water. One unit (IU) of $\alpha$-amylase was defined as the amount of enzyme releasing one $\mu \mathrm{mol}$ glucose equivalent per minute under the assay conditions.

\section{Estimation of soluble protein}

Soluble protein concentrations were determined in the aqueous extract of fermented matter by the method of Lowry et al.. (1951) using bovine serum albumin as standard.

\section{Partial purification and characterization of enzyme}

The crude enzyme was precipitated with ammonium sulphate. The sample was separated into three fractions based on the saturation percent of ammonium sulphate $(0-40 \%, 40-70 \%, 70-90 \%)$. The precipitation was carried out at $4^{\circ} \mathrm{C}$ under constant stirring and the precipitated proteins were centrifuged at $8000 \mathrm{xg}$ for $20 \mathrm{~min}$. The fractions were dialysed in $0.1 \mathrm{M}$ acetate buffer to remove the remaining salt. Specific activity of the enzyme was estimated in all the fractions. The enzyme was characterized by studying the effect of incubation time of reaction mixture $(5,10,15,20,25,30,35$ $\mathrm{min})$, effect of incubation temperature $(30,40,50$, $\left.60,70,80,90^{\circ} \mathrm{C}\right)$, effect of substrate concentration $(0.25,0.5,1.75,1.0,1.25,1.5,1.75 \mathrm{M})$, effect of enzyme concentration $(0.5,1.75,1.0,1.25,1.5,1.75$ $\mathrm{ml})$, effect of $\mathrm{pH}(3.6,4.0,4.4,4.8,5.0,5.4)$, and effect of metal ions ( $\mathrm{Na}, \mathrm{Ca}, \mathrm{Mn}, \mathrm{Mg}$, and $\mathrm{K}$ $1 \mathrm{mM}$ ) were determined.
SDS- PAGE and activity staining of alpha amylase: SDS-Polyacrylamide gel electrophoresis $(12 \%)$ of partially purified alpha amylase was performed for the determination of molecular weight in accordance with the procedure of Laemmli et al. (1970). Alpha amylase activity was localized by running the enzyme in a nativePAGE. The gel was immersed in soluble starch $(1 \%)$ in $0.1 \mathrm{~mol} \mathrm{l}^{-1}$ for $1 \mathrm{~h}$ at $25^{\circ} \mathrm{C}$. The gel was then kept in the same buffer, followed by staining with iodine solution $(0.05 \mathrm{~g}$ iodine and $0.5 \mathrm{~g} \mathrm{KI}$ in 100 $\mathrm{ml}$ of distilled water) for $5 \mathrm{~min}$ (Fig. 8).

\section{RESULTS AND DISCUSSION}

SSF was carried out with substrates such as coconut oil cake (COC), sesame oil cake (SOC), groundnut oil cake (GOC), palm kernel cake (PKC), olive oil cake (OOC), wheat bran (WB) for the production of alpha amylase with an initial moisture content of $64 \%$ at $30^{\circ} \mathrm{C}$ using $A$. oryzae for72h.

Among the oil cakes, GOC and PKC gave the highest and lowest yields of $\alpha$-amylase (5390 and $960 \mathrm{IU} / \mathrm{gds}$, respectively). With WB, the enzyme activity, however, was higher than GOC (6547 IU/gds) (Fig. 1). In view of this, studies were made to evaluate the mixed substrate fermentation using WB and GOC in different ratios $(1: 1,1: 2$, $1: 3$, and 1:4). Results were significant as the mixed substrate at 1:1 ratio increased the enzyme yields to $7053 \mathrm{IU} / \mathrm{gds}$ (Fig. 2). In further studies, hence this mixed substrate was used.

\section{Effect of supplementation of GOC/WB with carbon sources}

The supplementation of the mixed substrate with different carbon sources such as glucose, sucrose, maltose, lactose and starch at $1 \% \quad(\mathrm{w} / \mathrm{w})$ concentration showed increased production of the enzyme with lactose and maltose, which was 8663 and $8710 \mathrm{IU} / \mathrm{gds}$, respectively (in comparison to $7046 \mathrm{IU} / \mathrm{gds}$ in control). There are other reports describing similar findings that both the sugars generally induce the production of alpha amylase in different strains of $A$. oryzae (Yabuki et al. 1977, Eratt et al., 1984). While starch did not show any impact on enzyme synthesis, glucose and sucrose marginally inhibited the enzyme production (Fig. 3). 
Effect of supplementation of nitrogen source Studies on supplementation of inorganic and organic nitrogen sources such as peptone, corn steep solid, urea, sodium nitrate, ammonium sulphate, and ammonium nitrate at $1 \%(\mathrm{w} / \mathrm{w})$ concentration to the fermentation medium showed a mixed trend on enzyme production (Fig. 4). Among the organic sources, peptone was found to increase in the yield of enzyme but the other two inhibited the enzyme synthesis by the culture. Addition of ammonium nitrate to the medium produced $9196 \mathrm{IU} / \mathrm{gds}$ of alpha amylase, which was the best among all the nitrogen sources. Ammonium sulphate showed a negative influence, showing a steep decrease in the alpha amylase activity 5919 IU/gds (Fig. 4).

\section{Partial purification of the enzyme}

Up on partial purification, different fractions of enzyme showed different degree of enzyme activities (Table 1). The fraction with the maximum enzyme yield was $40-70 \%$. Hence, further characterization of the enzyme was done with this fraction.

\section{Characterization of partially purified alpha amylase}

Incubating the reaction mixture for different time showed influence on the activity of alpha amylase. At 5 min of incubation, there was maximum activity (33668 IU/gds) but as time of incubation increased there was gradual decrease in the enzyme activity, which was only $6051 \mathrm{IU} / \mathrm{gds}$ at 35 min (data not shown).

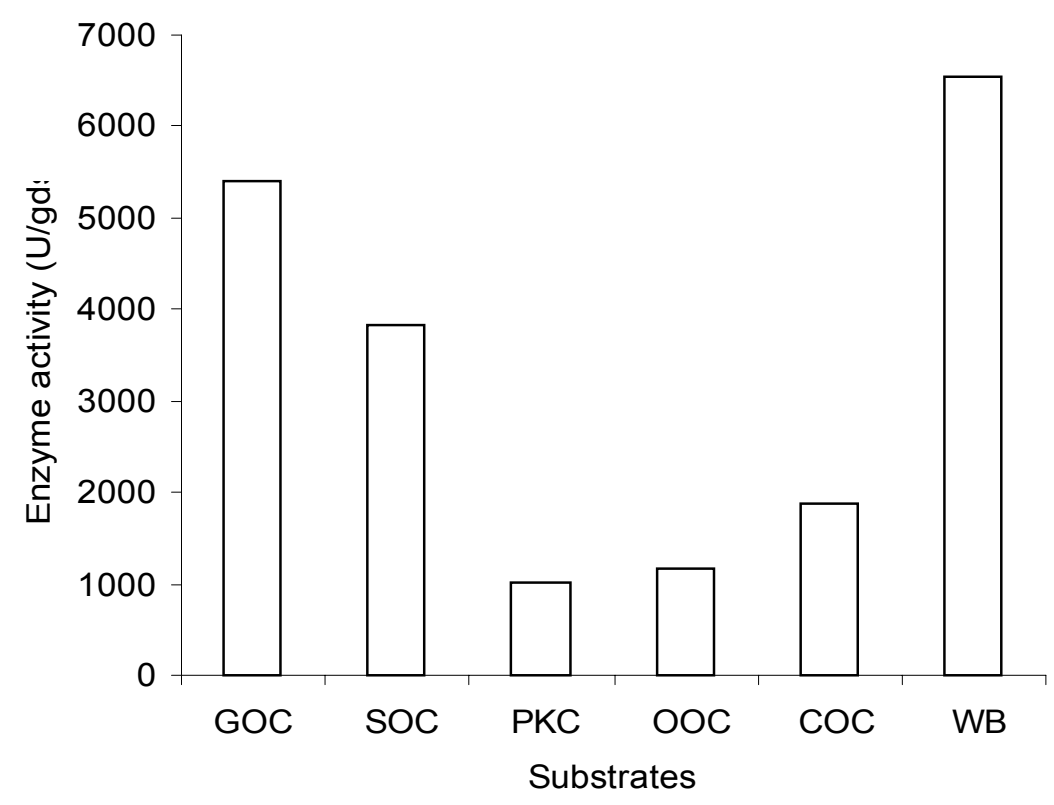

Figure 1 - Screening of individual substrates for the production of alpha amylase 


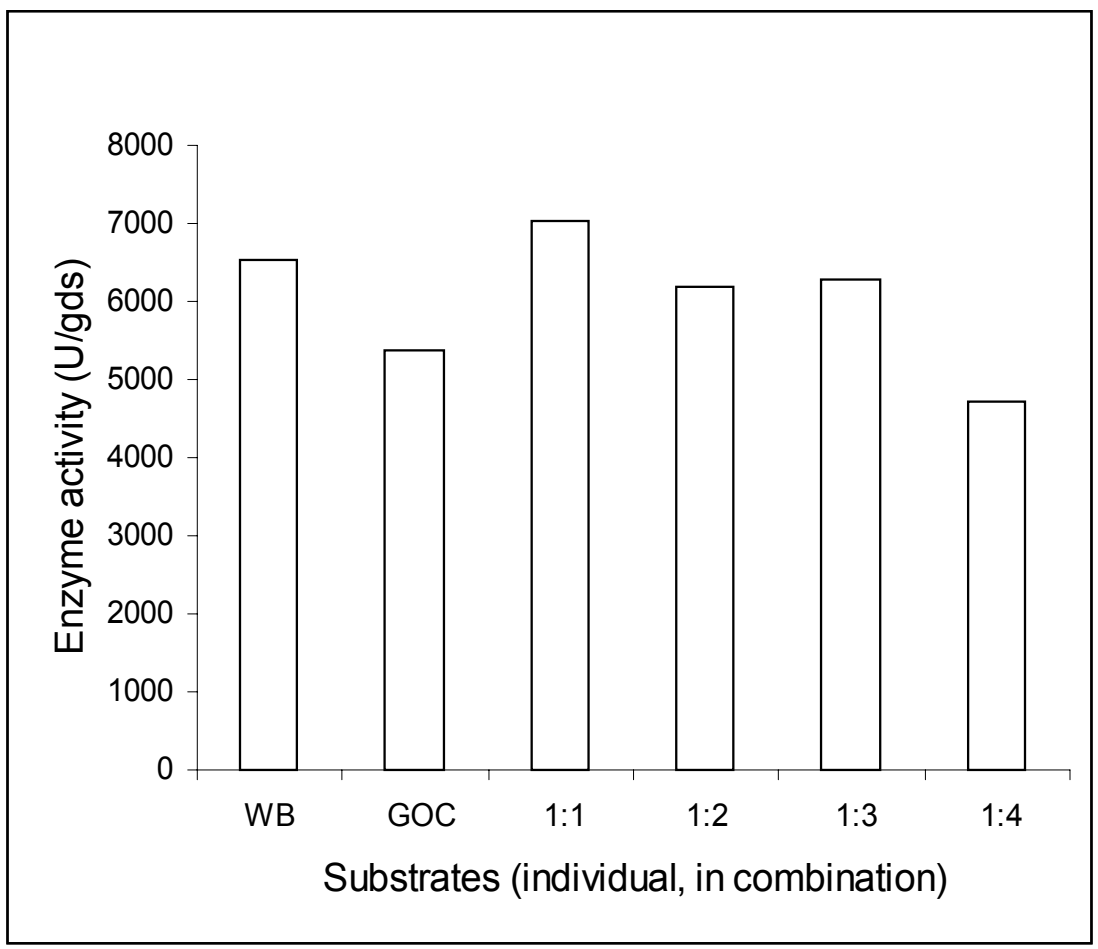

Figure 2 - Evaluation of mixed substrates for the production of alpha amylase

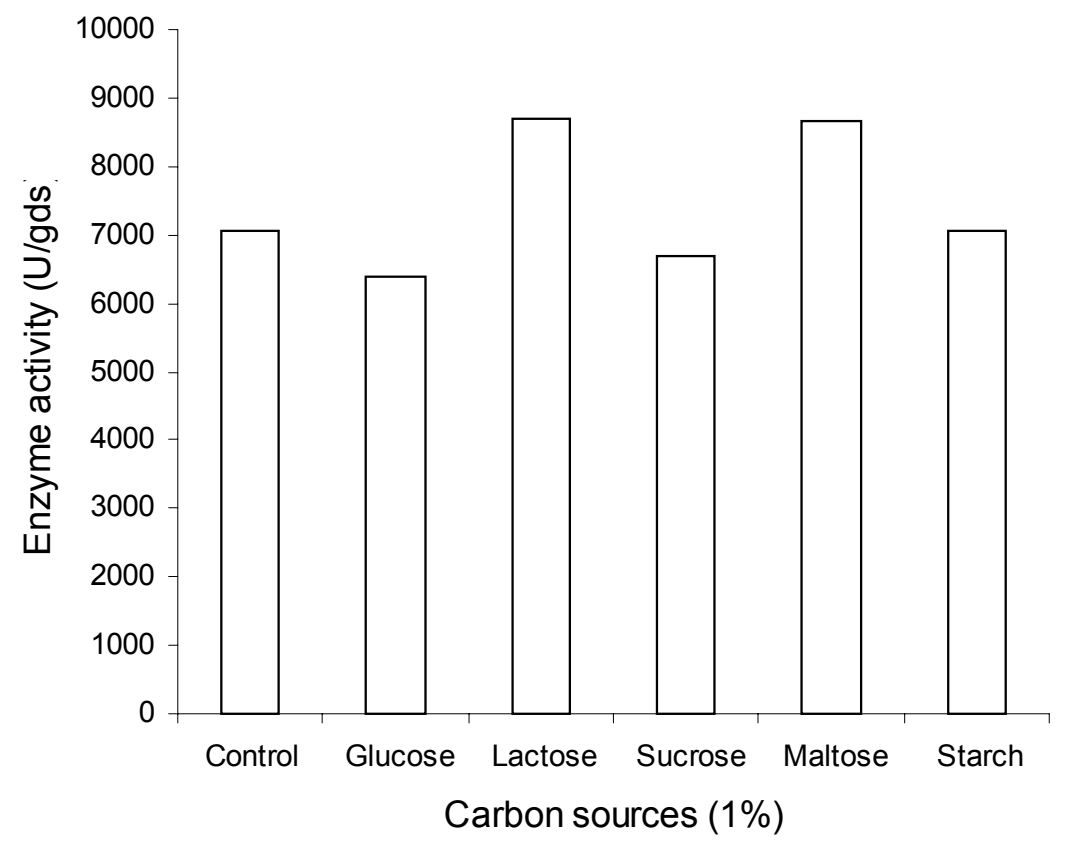

Figure 3 - Effect of supplementation of carbon source on enzyme production 


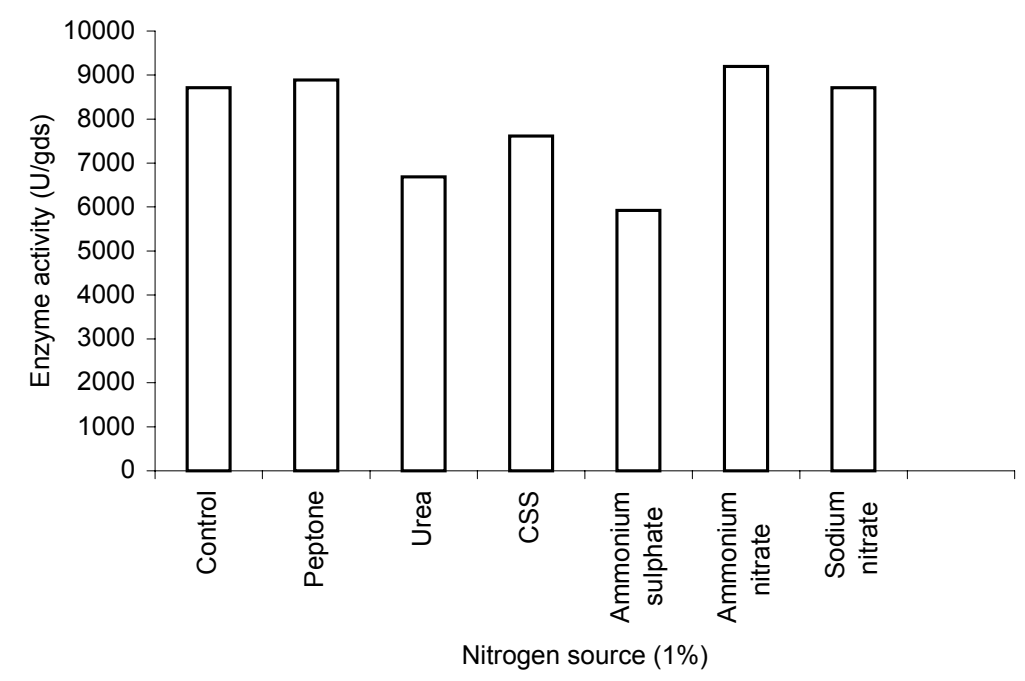

Figure 4 - Effect of supplementation of nitrogen source on enzyme production

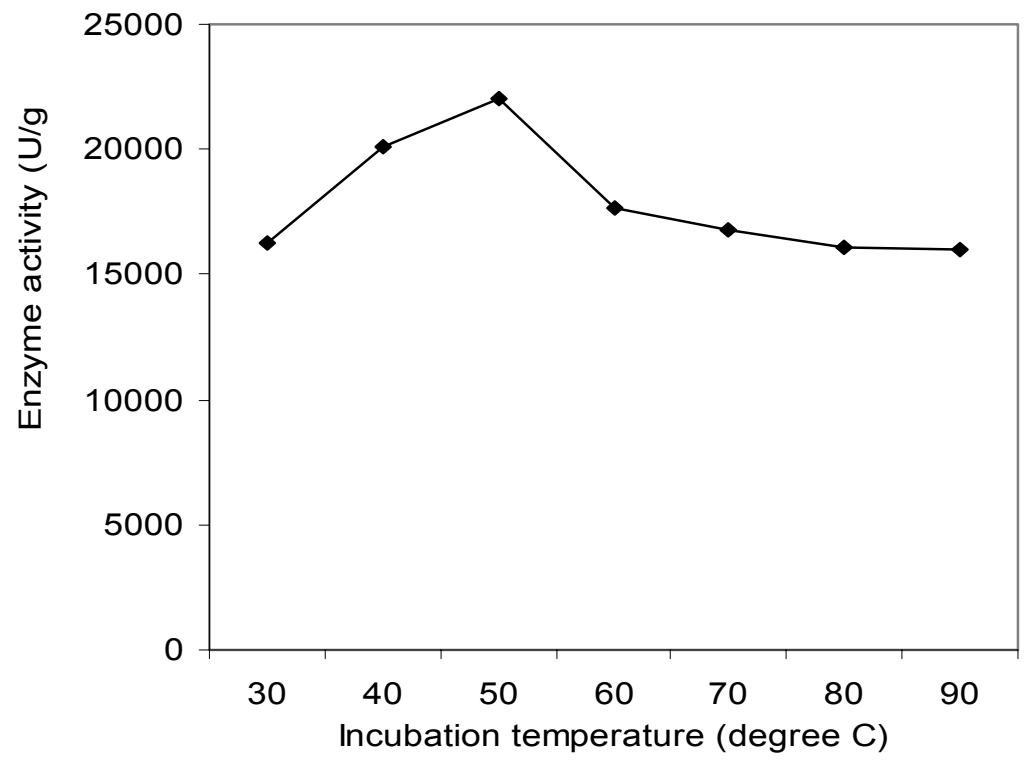

Figure 5 - Effect of incubation temperature on the activity of partially purified alpha amylase 


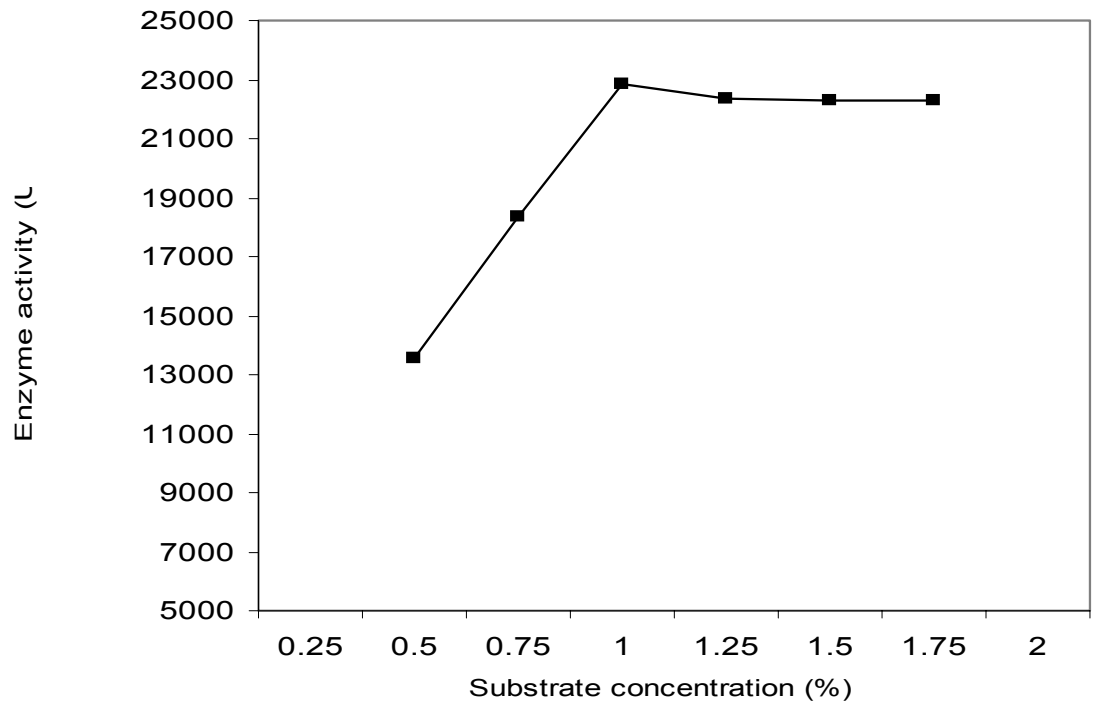

Figure 6 - Effect of substrate concentration on alpha amylase activity

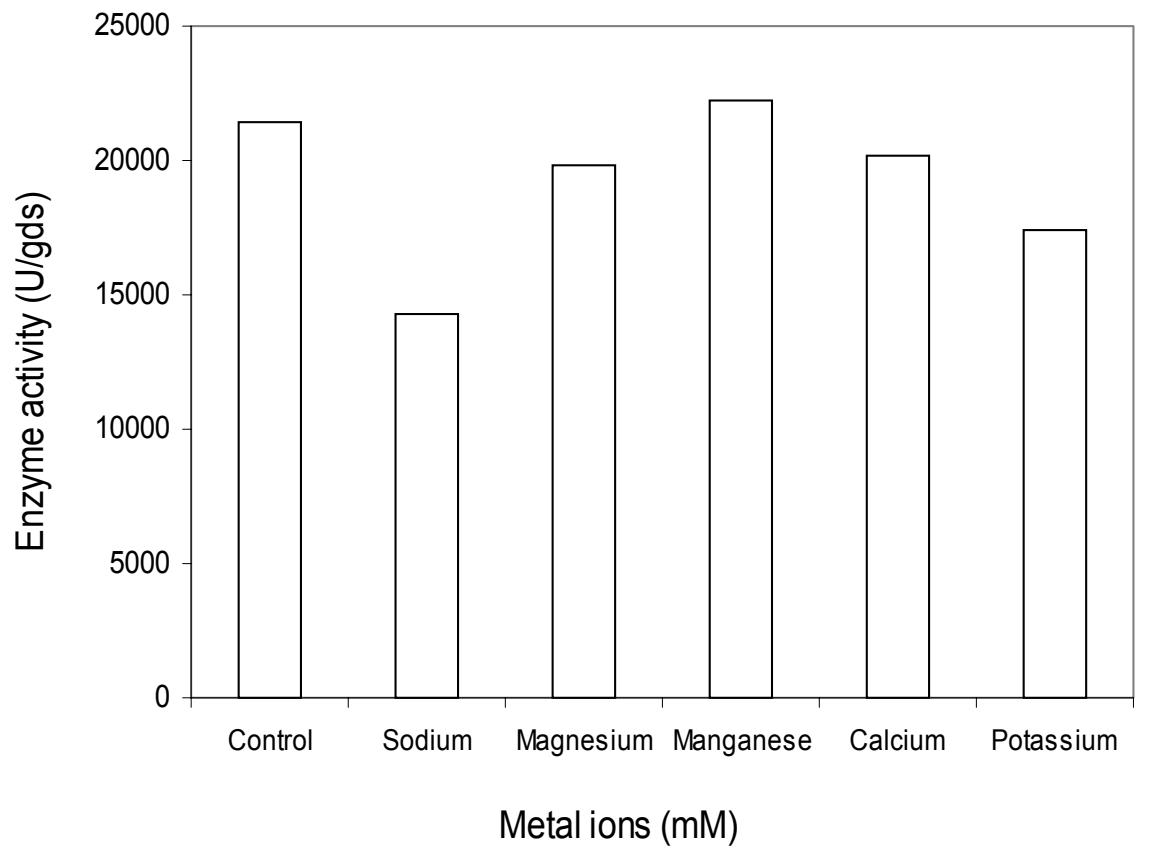

Figure 7 - Effect of metal ions on alpha amylase activity 
$\underline{\text { Table } 1 \text { - Specific activities of crude and partially purified samples }}$

\begin{tabular}{l|c|c|c}
\multicolumn{1}{c|}{ Samples } & $\begin{array}{c}\text { Enzyme activity } \\
\text { (U/gds) }\end{array}$ & $\begin{array}{c}\text { Protein content } \\
\text { (mg/gds) }\end{array}$ & $\begin{array}{c}\text { Specific activity } \\
\text { (U/mg) }\end{array}$ \\
\hline Crude & 9196 & 5.7 & 37.4 \\
$0-40 \%$ & 1076 & 3.3 & 10.0 \\
$40-70 \%$ & 21436 & 8.5 & 78.1 \\
$70-90 \%$ & 12630 & 7.0 & 55.1 \\
\hline
\end{tabular}

Studies on the effect of temperature of incubation showed that enzyme activity was maximum at $50^{\circ} \mathrm{C}$. Yabuki et al. (1977) have also reported similar results. Further increase in the temperature of incubation resulted in decrease in the activity of alpha amylase (Fig. 5).

Studies on the effect of substrate (starch) concentration on the alpha amylase showed specificity towards starch. Enzyme activity increased with the increase in starch concentration at $1 \%$, after which the activity remained stable with the increase in starch concentration (Fig. 6).

The study on the influence of different metal ions on alpha amylase activity indicated that the enzyme was considerably inhibited by $\mathrm{Na}^{2+}, \mathrm{Mg}^{2+}$, $\mathrm{K}^{2+}$. Interestingly $\mathrm{Ca}^{2+}$, which has been generally found to enhance and stabilize the alpha amylase activity at high temperature (Savchenko et al. 2002) was found to inhibit the alpha amylase activity, although marginally. Alpha amylase from A. oryzae EI212 was also reported to be inactivated in the presence of calcium (Kundu and Das, 1970). Among the metal ions, manganese was found to enhance the activity (Fig. 7).

\section{Activity staining and molecular weight determination}

Activity staining of alpha amylase showed pale yellow band in the dark colored gel, which confirmed the enzyme activity. (picture not shown). Molecular weight of partially purified enzyme was found to be approximately $68 \mathrm{KDa}$.

\section{ACKNOWLEDGEMENTS}

We thank Dr M Jaafar Daud, MARDI, Kuala Lumpur, Malaysia for kind gift of PKC. We acknowledge the grants under Indo-Hungarian bilateral collaboration from DST, New Delhi and TeT Foundation, Budapest.

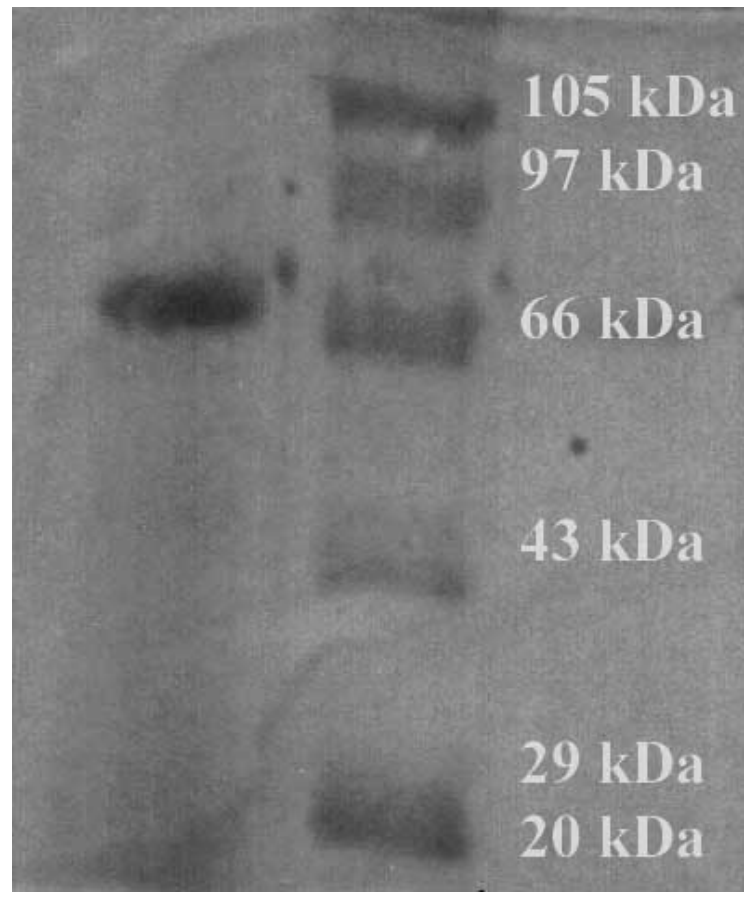

Figure 8 - SDS-PAGE of partially purified alpha amylase

\section{RESUMO}

Fermentação no Estado Sólido foi empregada na produção de alfa-amilase usando Aspergillus niger. Diferentes tipos de torta foram utilizadas, como torta de óleo de coco (COC), torta de de óleo de amendoim (GOC) torta de óleo de sesamo (SOC), torta de palma (PKC) e torta de óleo de oliva (OOC) foram selecionadas para serem usadas como substratos para produção de enzima e comparadas com o farelo de trigo (WB), GOC foi escolhido por ser o que produziu maiores concentrações de enzima. A combinação WB e GOC (1:1) resultou em maiores títulos da enzima quando em comparação com os substratos individuais. A máxima concentração de enzima (9196 U/ gms) foi obtida quando a FES foi conduzida utilizando $\mathrm{WB}+\mathrm{GOC}$, com umidade 
de $64 \%$ e suplementada com lactose e nitrato de amônia (1\% cada) a 300C por 72 horas utilizando $2 \mathrm{~mL}$ de uma suspensão de esporo (6x107sporos $/ \mathrm{ml})$. A purificação parcial da enzima usando frações de sulfato de amônio resultou num aumento de 2-4 vezes o aumento da atividade. A enzima apresentou um peso molecular de $68 \mathrm{Kda}$ pelo SDS_PAGE. Exceto Mn, todos os outros íons metálicos como $\mathrm{Ca}, \mathrm{K}, \mathrm{Na}, \mathrm{Mg}$ são inibitórios na produção da enzima.

\section{REFERENCES}

Benjamin, S. and Pandey, A. (1997), Coconut cake: A potent substrate for production of lipase by Candida rugosa in solid-state fermentation. Acta Biotechnol., 17, 241-251.

Benjamin, S. and Pandey, A. (1998), Mixed solid substrate fermentation: A novel process for enhanced lipase production by Candida rugosa. Acta Biotechnol., 18, 315-324.

Benjamin, S. and Pandey, A. (1996), Lipase production by $C$. rugosa on copra waste extract. Indian Journal of Microbiology., 45, 452-456.

Carlsen, M.; Sphor, A. B.; Nielsen, J. and Villadesn, J. (1996), Morphology and physiology of an $\alpha$-amylase producing strain of Aspergillus oryzae during batch cultivation. Biotechnol Bioeng., 4, 266-276.

Carrizales, V. and Jaffe, W. (1986), Solid state fermentation an appropriate biotechnology for developing countries. Interscience, 11, 9-15.

Eratt, J. A.; Douglas, P. E.; Moranelli, F. and Seligy, V. L. (1984), The induction of alpha amylase by starch in Aspergillus oryzae: Evidence for controlled mRNA expression. Canadian Journal of Biochemistry and Cell Biology, 62, 678-690.

Francis, F.; Sabu, A.; Nampoothiri, K. M.; Ramachandran, S.; Ghosh, A.; Szakacs, G. and Pandey, A. (2003), Use of response surface methodology for optimizing process parameters for the production of $\alpha$-amylase by Aspergillus oryzae. Biochemical Engineering journal, 107, 115.

Kundu, A. K. and Das, S. (1970), Production of amylase in liquid culture by a strain of Aspergillus oryzae. Applied Microbiology, 19, 598-603.

Laemmli, U. K. (1970), Cleavage of structural protein during the assembly of the head of bacteriophage T4. Nature, 227, 680-685.

Lowry, O. H.; Rosenbough, H. I.; Fair, A. L. and Randall, R. I. (1951), Protein measurement with the Folin phenol reagent. J. Biol. Chem., 193, 265-275.

Miller, G. L. (1959), Use of dinitrosalicylic acid reagent for determination of reducing sugar. Analytical Chemistry, 31, 426-429.
Okolo, B. N.; Ezeogu, L. I. and Mba, C. N. (1995), Production of raw starch digestive amylase by Aspergillus niger grown on native starch sources. Journal of Science of Food and Agriculture, 69, 109-115.

Pandey, A.; Selvakumar, P.; Soccol, C. R. and Nigam, P. (1999), Solid-state fermentation for the production of industrial enzymes, Bioresource technology, 77 : (1), 149-162.

Pandey, A.; Soccol, C. R.; Nigam, P. and Soccol, V. T. (2000), Biotechnological potential of agro-industrial residues. I: sugarcane baggase, Bioresource technology, 74, 69-80.

Pandey, A.; Soccol, C. R. and Mitchell, D. (2000), New developments in solid-state fermentation, Ibio-processes and applications, Process Biochemistry, 35, 1153-1169.

Pandey, A.; Soccol, C. R.; Rodriguez, L. J. and Nigam, P. (2001), Solid-state fermentation in biotechnology., New Delhi : Asiatech Publishers. pp. 221.

Raimbault, M. (1998), General and microbiological aspects of solid substrate fermentation, EJB Electronic J Biotechnol, 1, 1-20.

Savchenko, A.; Vielle, C.; Kang, S. and Zeikus, G. (2002), Pyrococcus furiosus $\alpha$ - amylase is stabilized by calcium and zinc. Biochemistry, 41, 6193-6201.

Selvakumar, P.; Ashakumary, L. and Pandey, A. (1998). Biosynthesis of glucoamylase from $A$. niger by solid-state fermentation using tea waste as the basis of a solid substrate. Bioresource Technol, 65, 83-85.

Singh, K.; Garg, S. K.; Kalla, A. and Bhatnagar, A. (2003), Oilcakes as protein sources in supplementary diets for the growth of Cirrhinus mrigala (Ham.) fingerlings: laboratory and field studies. Bioresource Technology., 86, 283-291.

Swick, R. A. (1999), Considerations in using protein meals for poultry and swines, ASA Technical Bulletin, AN21, 1-11.

Received: November 18, 2002; Revised: January 09, 2003 ; Accepted: March 15, 2003. 